\title{
Science and religion: a rocky relationship shaped by shared psychological functions
}

\author{
Bastiaan T. Rutjens \\ University of Amsterdam \\ $\&$ \\ Jesse L. Preston \\ University of Warwick
}

Chapter to appear in Vail, K., \& Routledge, C. (Eds.) The science of religion, spirituality, and existentialism. Elsevier: Academic Press.

Please address correspondence to Bastiaan T. Rutjens, University of Amsterdam (e-mail: b.t.rutjens@uva.nl)

\begin{abstract}
This chapter reviews work on the shared psychological functions of science and religion. In doing so, we focus on three of these functions that are of particular importance to human functioning: explanation, control, and meaning. The research that is reviewed indicates that both belief systems can help to address motivational needs pertaining to these functions, albeit in different ways and with somewhat different degrees of success. Morality and mortality are two central domains within which this notion is further explored. We conclude that the psychological functions that belief systems fulfil form a central component of both science and religion, as well as of their complicated relationship.
\end{abstract}




\section{Science and religion: a rocky relationship shaped by shared psychological functions}

How do we understand the relationship between science and religion? Why do they sometimes seem to conflict, sometimes complement each other, and at other times be completely unrelated to each other? Though science and religion differ in underlying assumptions, they share important psychological functions for explanation, control, and meaning. How these functions are fulfilled varies with different religious and scientific beliefs, and so does the nature of the relationship between science and religion. In this chapter we explore the relationship between science and religion by adopting a functional psychological approach. Differences in underlying processes shape how those functions are fulfilled. This can be seen particularly in how science and religion approach two central existential concerns: morality and mortality. Whether or not science and religion conflict, complement, or operate independently is a result of the particular ways these functions are expressed and whether their explanatory narratives can be reconciled.

\section{Science and religion: A brief history.}

Science and religion have had a long and complicated relationship, as they both serve as means of exploring the meaning of the natural world. The ancients often practiced religion and science hand in hand: observations of the stars and seasons were intertwined with theologies and integrated with important social rituals. As human history progressed, scientific and religious practices each became more elaborate and specialized. By the beginning of the scientific revolution, Christianity had come to dominate European society, impacting on almost every aspect of life - including ideas about the physical world. When Western science started to make important advances at this time, various conflicts with the church ensued. Famous examples include the persecution of Galileo Galilei in the $17^{\text {th }}$ century - for endorsing the heliocentric 
model that threatened the view that the Earth is the center of the cosmos-and later in the $19^{\text {th }}$ century, Charles Darwin's theory of evolution by natural selection.

Yet science and religion have never been entirely adversarial. Many scientists through the ages have been strongly religious, and saw their science as evidence for the divine, for example Kepler, Newton, Boyle, and Faraday. Some prominent $20^{\text {th }}$ century scientists (Like Einstein and Hawking) made allusions to God and the divine in their work, though these may be more metaphorical than a literal devotion to God. And other scientists argue that while neither conflict nor synthesis between science and religion are the answer, the best way is to keep scientific and religious enterprises separate (Gould, 1997).

The complicated relationship between science and religion thus seems to take on different forms. Ian Barbour (1997) identified four different general attitudes toward the relationship between science and religion:

1. Science and religion are fundamentally incompatible with each other and must be in conflict. In this view, either science or religion may be correct, but not both.

2. Science and religion are separate enterprises. This is clearly expressed by Stephen Gould's proposal for "non-overlapping magisteria"), meaning that they cover different domains of knowledge (Gould, 1997). Here we can use whichever system is most appropriate for the situation. Where religion may be most appropriate for existential questions and morality, science may be most appropriate to answer concrete answers about nature.

3. Science and religion are both complementary and compatible. Science and religion are ultimately answering the same questions, and although they approach in different directions, they support each other. This is exemplified by the popular idea that 
"science explains how, religion explains why." Francis Bacon, and Galileo too, used the allegory of Two Books (one book is for theologians, one is for scientists/philosophers); the Two Books are complimentary and—crucially—are written by the same Author.

4. Science and religion should be in dialogue. Religion and science are neither in conflict nor entirely compatible, but they this does not mean they need to be kept separate. Where they are different, they each have much to say to each other and offer the other in wisdom. This view holds that the best relationship between science and religion arises from a mutual respect and dialogue from which they may learn from each other.

Why do we see such different attitudes toward the relation between science and religion? Common to all these different perspectives is the insight that science and religion share fundamental goals for understanding, order, and ultimately a sense of meaning. As we argue here, the nature of the relationship between science and religion is informed by how each address these key psychological functions. Below, we describe these shared psychological functions of religion and science in more detail, and how these guide the relationship between them.

\section{Science and religion: Key shared functions}

Various programs of research show that both religions and secular scientific institutions can help manage at least some existential concerns, and the evidence for this is particularly strong for the motivation to maintain perceptions of the world as orderly and under control (Laurin \& Kay, 2017; Rutjens et al., 2013; Rutjens et al., 2018). Religion has been found to address several key existential concerns; these include the needs to manage the awareness of mortality, to feel unique yet socially connected to others, and to maintain the belief that the world is orderly and controllable, among others (Sedikides, 2010). Crucially, however, 
sometimes science can also provide for such existential-motivational needs (Rutjens, van der Pligt, \& van Harreveld, 2013). As scientific advances continue to emerge, they can often have the effect of encroaching on religion's turf via technological and informational progress. In this chapter, we review some of the available research on the common psychological-motivational functions of science and religion—-focusing on explanatory needs, need for control, and the need for meaning — and how these functions affect their relationship.

Need for explanation. One of the most important functions of religion and science is that they each provide explanations for nature and the world we live in. Throughout history, people have used gods to explain changes in the seasons, weather, historical events, and the passing of life and death itself. Science, too, is driven toward explaining the unexplained, from the origins of life to the end of time. This desire for causal explanation is more than an idle passing, but a primary cognitive and motivational drive (Weiner, 1985; Keil, 2006). Unexplained events immediately draw our attention and cause distress until resolved (Hassin, Bargh, \& Uleman, 2002).

But some explanations are more satisfying than others. When a single cause is able to explain more phenomena, it becomes more powerful (Thagard, 1989). As an example, a factor known to contribute to one case of a specific kind of cancer is less significant than a cause that contributes to all cases of all forms of cancer. Broadly speaking, religion has extraordinary explanatory power. The concept of gods — especially omnipotent creator gods — potentially may be used to explain everything. The more that religion is used as an explanation, the more meaningful it should become. This was explored experimentally in a series of studies looking at the explanatory power of both religion and science (Preston \& Epley, 2005). In one study, people were asked to write few or many things that God's actions could explain. Those asked to list 
many phenomena subsequently reported that their belief in God was more meaningful and important to them, compared to those that listed only a few. As religious explanations became more comprehensive, they increased in value. The same was true for scientific explanations. People rated a psychology theory as more meaningful and important when asked to think of many phenomena it explained, compared to who listed just a few phenomena the theory explained. However, when people listed what could explain the psychological theory (i.e., its mechanisms), the theory became less important and meaningful. This is one instance in which religion has a clear advantage over science. In science, it may be possible to find more and more fundamental mechanisms, diminishing the explanatory power as causation is relegated to a more primary source. In religion, there is no more primary cause than God - the alpha and the omega, or prime mover. Indeed, in these studies, when people were asked to explain God's actions, they were not able to do so (Preston \& Epley, 2005). In this way God may serve as an ultimate explanation (Preston \& Epley, 2005; 2009) - capable of explaining everything, without itself being explained.

Like religion, science also aims to explain all phenomena, and so also has the potential to be an ultimate explanation. One day, physicists may be able to produce a true "theory of everything" that summarizes the fundamental laws of physics into a single equation (Hawking, 2006; Laughlin \& Pines, 2000). Indeed, while the questions asked by both science and religion might be the same (e.g., where did we come from?), the answers are often different, and sometimes diametrically opposed. This is where the relation between science and religion becomes complicated because, as ultimate explanations, religion and science compete for the same explanatory space, which leads to conflict (Blancke et al., 2012; McCauley, 2011; Preston \& Epley, 2009; Rutjens, Heine, Sutton, \& van Harreveld, 2018; Thagard \& Findlay, 2010). As a 
result, the value of either science or religion as an ultimate explanation can also impact the value of the other: actively using religious explanations reduces positive evaluations of science, and vice versa (Preston \& Epley, 2009; Preston, Ritter, \& Hepler, 2013). More telling is the "Godof-the-Gaps" effect (Preston \& Epley, 2009)—when scientific explanations for the origins of life and the universe seem weak (not being able to explain) positive evaluations of God increase. A similar effect was later found for belief in the soul and the so-called "explanatory gap" of consciousness (Preston, Ritter \& Hepler, 2013). When neuroscience explanations for important experiences of the mind were given (e.g., conscious will and romantic love), they diminished participants' belief in a soul. But only when the neuroscience mechanisms provided a strong explanation. When neuroscience was framed as a weak account for these experiences, people reported stronger belief in a soul and were less willing to "sell" their soul to an experimenter. Thus, it appears that when science fails to provide explanations for these big questions, people turn to religion as an alternative explanation to fill in the gap. This might also explain why religious orthodox individuals especially struggle to accept science and scientific evidence (Rutjens et al., 2018) or notions of moral progress (Rutjens et al., 2016).

However, this is not to say that there is always an explanatory conflict between science and religion. Their relationship depends on the particular explanations each rely on. These can be inconsistent explanations; for example, the Big Bang is inconsistent with specific creation myths that specify Earth is a few thousand years old. On the other hand, the idea of a singularity proposed at the beginning of the Big Bang is consistent with the idea of a god that created the universe. In many instances people can synthesize scientific and religious explanations for various processes and phenomena. For example, people can combine scientific explanations with magical thinking in order to explain a disease like AIDS (Legare, Evans, Rosengren, \& Harris, 
2012), and are able to endorse various natural and supernatural explanations for unusual events simultaneously, such as winning a large sum of money or being caught in extreme weather for a significant amount of time (Woolley, Cornelius, \& Lacy, 2011).

Need for control. People are not only motivated to explain the world in which they live, but to maintain control over outcomes in the world. While explanation can be considered to be purely epistemological, control is a psychological motivation that is considered a basic human need with far-reaching consequences for health and well-being (e.g., Heckhausen \& Schulz, 1996; Rutjens \& Kay, 2017; Thompson \& Spacapan, 1991). If direct personal control is not possible, people turn to external sources of control (Kay et al., 2008; Rothbaum, Weisz, \& Syder, 1982) as a means of providing predictability and order. Science and religion can both function as important sources of control and order in the universe.

A major motivation of science is to provide a sense of order and control (for reviews see Rutjens et al., 2013; Rutjens et al., 2018). Indeed, it is not hard to see how science can help provide order and predictability to the world, and how technology helps humans to affirm and extend their control over the natural world, both on a collective level and on an individual level. As Richard Dawkins famously explained in 2013 (we direct the interested reader to https://www.youtube.com/watch?v=0OtFSDKrq88), science helps to control the world because it works: planes designed on science fly and medicine based on science cures people. Some kinds of science are better than others at providing control, however. For example, theory of evolution is an undirected process that uses randomness in mutations as its primary impetus - a chaos that is not particularly comforting. As a result, some kinds of scientific ideas may be preferred over others when there is a need for control. This is exactly what was found in an early study on framing of evolutionary theory either conferring order or defying order (Rutjens, van Harreveld, 
\& van der Pligt, 2010). People who felt a threat to sense of control preferred to shift away from the theory of evolution, in favor of intelligent design - a theory with more religious implications, and also a clearer sense of order than the random processes of evolution. This push towards intelligent design was no longer found, however, when evolution was presented as an orderly and predictable process. In both cases, evolution provided a strong scientific explanation, but framing evolution as orderly (and predictable) had an impact on its appeal to individuals who felt a threatened sense of order. A similar finding was reported in research by Rutjens, van Harreveld, van der Pligt, Kreemers, and Noordewier (2013), which examined whether stage theories in science are more appealing than their continuum theory counterparts, presumably because they offer a more clear-cut and predictable temporal order. By positing clear categories and fixed sequences, stage theories afford a more orderly account of various processes and phenomena than equivalent theories positing continuous processes. In the research, short descriptions of stage theories and continuum theories, for example about grief and moral development, were presented to participants who were assigned to a control-threat, controlaffirmation, or neutral condition. Lower perceptions of control led to an increase in the appeal of stage theories. Interestingly, these effects were found even when the sense of order provided had negative implications; for example, a preference for a pessimistic (yet order-providing) stage theory of Alzheimer's disease. As another example, although being diagnosed with Huntington's disease is a negative experience, those who get a diagnosis (as opposed to those whom decided they did not want to know) are happier later on because their diagnosis gave them answers (Heine, 2017). Though counterintuitive, positive experiences can be less appealing and negative experiences more satisfying depending on the predictability these confer (Rutjens et al., 2013; Landau, Kay, \& Whitson, 2015; Wilson, Centerbar, Kermer, \& Gilbert, 2005). 
Interestingly, research has similarly found that some, but not all, religious ideas satisfy the need for order and control. Kay and colleagues (2008), found that a threat to control led to an increase in belief in God, but only when described as a controlling God. Various follow-up studies have resulted in further evidence for the notion that belief in powerful, controlling gods - as opposed to non-intervening gods, or a God that "works in mysterious ways"—-helps fulfill people's need for order and control (e.g., Laurin et al., 2010; Kay, Landau, Khenfer, \& Keefer, 2017; Khenfer, Laurin, Tafani, Roux, \& Kay, 2017).

Thus, for science as well as for religion— both of which are multifaceted and complex belief systems or worldviews - how well they satisfy the needs for order and control depends on the specific interpretation of the worldview. Science and religion can both provide external control, and in doing so seem to function in relatively similar ways (i.e., there has to be an element of order and predictability to the worldview). But unlike explanation, control is not easily shared by different sources simultaneously. Either science or religion can provide a source of external control, but not both, at least not within the same domain. Research on compensatory control more generally finds that sources of external control function in hydraulic ways, so that bolstering beliefs in one reduced the need to bolster another. Ultimately, control must lie in a single source, and any synthesis between religion and science requires that power be conceded to one or the other.

Need for existential meaning. Another key psychological need is to perceive life as meaningful (Steger et al., 2016), and so people search for and invest in belief systems and worldviews that satisfy this need by bestowing existential comfort. Meaning is correlated with various indices of health and well-being (e.g., Steger \& Frazier, 2015), and is closely related to religiosity (Abeyta \& Routlegde, 2017; Newton \& McIntosh, 2013; Rutjens \& van Elk, 2019; 
Wojtkowiak, Venbrux, \& Rutjens, 2010). Religious systems provide their believers with an invaluable sense of purpose, moral meaning, connection to others, and connection to the past and future.

Can science create meaning too? Feelings of meaning are often accompanied by a deep sense of awe and reverence, that can be found through both religion and science. Recalling spiritual experiences activated feelings of awe and spiritual humility (Preston \& Shin, 2017), and likewise feelings of awe appear to activate a readiness for spiritual experiences (Van Cappellen, \& Saroglou, 2012). But awe can be evoked by scientific explanation as well (Valdesolo, Park, \& Gottleib, 2016) and may help facilitate science learning (Valdesolo, Shtulman, \& Baron, 2016). Recently, Rutjens and Van Elk (2019) have investigated whether belief in science and knowledge about science are related to perceptions of meaning in life. Meaning in life was measured using various questionnaires and measures, and samples from various populations (North-America, The Netherlands, and India) were tested. The results were consistent across populations; zero-order correlations revealed that the relation between belief in science and meaning in life were either negative or non-existent. Knowledge of science was not related to meaning in life. In contrast, religiosity was positively correlated with meaning in life in all studies. Additionally, it was found that belief in science did not explain any variance in regression analyses predicting perceptions of meaning, whereas religious faith was a significant positive predictor across populations. However, it was also found that for people scoring low on religious belief, placing more importance on science as central to their identities (Bender et al., 2016) predicted stronger perceptions of meaning. Likewise, recent work has found that, while belief in science was not correlated with meaning, people who felt stronger Spirituality of Science (Preston \& Coleman, 2019) - a sense of transcendence and awe is applied to science- 
reported greater meaning-seeking and personal meaning. Again, experiencing awe through science appears to play a key role to feeling meaning, Indeed, some recent work by Johnson and colleagues (2019) shows that while science can diminish belief in God by competing logical arguments, science can promote religious belief through awe. This suggests that -at least for some - science is related to the motivation to find meaning, and the quest for meaning might be fulfilled via science (Preston, 2011).

Critically, these existential functions are distinct from epistemic functions (i.e., search for causal explanation) and control. English nature writer Richard Jefferies remarked: "I do not venture, for a moment, even to attempt to supply a reason to take the place of the exploded plan... I look at the sunshine and feel that there is no contracted order: there is divine chaos" (Jefferies, 1887; in Gray, 2011). The quote highlights the importance of distinguishing between different motivations that underlie belief in science and belief in religion - but also suggests that meaning can exist either with or without connections to predictability and order. Order, predictability, and control do not guarantee meaning, awe, and significance. At the risk of being overly reductionist, a useful distinction is that some psychological functions of beliefs and worldviews are primarily epistemic and control-oriented (i.e.., need to know, to explain, to predict), while others are more meaning-oriented and existential (i.e., the moral landscape, the purpose of life; Crumbaugh \& Maholick, 1964). This is not to say that this distinction is categorical, but rather that mapping the extent to which psychological functions of beliefs and worldviews lean more towards the "how" versus the "why" can be helpful. Additionally, it is important to note that different motivations probably do not always converge, and the relation between science and meaning is perhaps more complex than that between science and explanation and control. Put differently, the meaning-oriented functions of science are likely less 
obvious for many — and more contingent on individual differences in religious beliefs and perhaps educational level and academic interest — than the epistemic or control-oriented functions of science. As an example, consider how the laws of nature as described by evolutionary theory may explain the world and render it orderly and to a certain extent predictable or even controllable, but supplanting creationist beliefs (e.g., intelligent design) with it may leave believers vulnerable to a void in existential meaning.

Science and religion both provide key existential functions. Both systems of belief can be personally fulfilling, provide meaning, and even a sense of awe. Meaning in science and religion may be connected to the worldviews they provide, including explanations and sources of control. Because meaning is so important, the value we place on these worldviews can make us defensive and hostile to ideas that might threaten those values. But the meaning derived by science and religion do not need to compete in the way epistemic beliefs do. Unlike explanations and control, meaning is not a zero-sum game. Rather, meaning from science and religion may be additive and enhance each other (as in Bacon and Galileo's Two Books metaphor mentioned earlier in this chapter).

\section{Differences in processes: Assumptions and biases}

Science and religion share common goals for understanding, order, and meaning. But where the two sharply divide is in their underlying processes, both in terms of the causal mechanisms that each rely on, and the cognitive styles related to scientific and religious thinking. These differences shape the forms that religious and scientific ideas take, and the relationship between the two.

Firstly, science and religion differ in basic assumptions about the fundamental causal mechanisms that underlie nature and the universe. Science presumes that the universe is 
governed by natural, ordinary, physical forces, that can be expressed by set laws. Religion, in contrast, assumes powers that are supernatural, extraordinary, and metaphysical, and that may defy understanding and prediction. That is, science relies on a physical stance toward causal reasoning, rather than an intentional stance where actions are caused by the intentions of an agent (Dennett, 1987). People can variably adopt physical or intentional stances to make sense of either objects or agents, respectively. For example, a physical stance may be useful for understanding why a bus stops working, but an intentional stance is more useful for understanding why a bus driver stops working. But humans are quick to infer agency and intention as a default (Guthrie, 1993; Haselton \& Nettle, 2006; Van Elk, Rutjens, van der Pligt, \& van Harreveld, 2016), which appears to be a hyper-sensitive bias evolved to help detect threats from predators and enemies. As such, people may also default to the intentional stance when faced with fear or uncertainty (Valdesolo, \& Graham, 2014), and anthropomorphize inanimate objects that seem to behave in unexpected ways (Morewedge, 2009). Intuitive biases to detect agency can be co-opted by religious thinking through the belief in unseen gods operating behind the scenes. One view on the origin of religious belief is that it an ultimate anthropomorphization: Perceiving an almighty supernatural god as the embodiment of the machinations of the universe (Guthrie, 1993). One difference between science and religion, therefore, may be different inclination toward mechanistic causes vs. mentalistic causes. Indeed, religious people seem to possess stronger tendency to perceive minds than less religious individuals (Gervais, 2013a). Relatedly, science and religion rely on different ways of "knowing" as a basis for belief. In science, knowledge is based on reason and empirical evidence: hypotheses are generated based on past observation and scrutinized through rigorous testing. But for religion, evidence is not as important as faith - a trust in knowing that transcends observation. To believe something 
is to believe something, and faith needs no other basis. Value of faith over evidence reflects an emphasis on intuition and feeling in reasoning. Indeed, the preference for intuitive vs. analytical reasoning may predict the system people most believe in, with religious people relying on more intuitive thinking (Shenav, Rand \& Greene, 2012). These differences are reflected in basic language use - in a sample of Christian and atheist Twitter users, atheists were more likely to use words that reflected cognitive processes, such as "because" (Ritter, Preston, \& Hernandez, 2014), suggesting more analytical concerns in general. But more telling, the groups also differed in their specific types of causal language: whereas atheists used more tentative and analytical language (it seems, I think), Christians used language that reflected more emotion and intuition (I know, I feel) in their everyday language.

Religious thinking and scientific thinking therefore differ in more than their content, but in their cognitive style. Religious thinking can be more intuitive than scientific thinking and can incorporate many different intuitive biases into religious concepts. Science, however, can sometimes be "radically counterintuitive" (e.g., McCauley, 2011. pp. 107-117). It is not easy for human beings to grasp abstract concepts such as the timescale of evolution or the laws of physics (e.g., the second law of thermodynamics; general relativity). A proper understanding of such insights requires years of scientific training, which has led to the idea that science does not come naturally to humans (McCauley, 2011). In contrast, religious concepts are free to co-opt intuitive thinking in a way that science cannot. Various cognitive biases can facilitate religious belief (Barrett, 2000; McCauley, 2011; Norenzayan, 2013; Shtulman, 2017)—as described by byproduct theories of religion (Atran \& Norenzayan, 2004; Barrett, 2000). Religious mythologies take on many intuitive characteristics, increasing how compelling they feel to a believer. When religion is counter-intuitive, it is often just counter-intuitive enough to keep 
interest (Norenzayan et al., 2006) and to make its ideas more memorable and transmittable to other believers.

This different reliance on intuitive biases can be seen through the role of essentialism in religious thinking. Essentialism refers to the perception of the objects, people, and other entities in natural world as emerging from invisible and immutable essences (Cimpian \& Salomon, 2014). Essentialism biases shape the judgment and perceptions of both abstract and concrete concepts, found in various populations across the world (Henrich, Heine, \& Norenzayan, 2010). For example, essentialist thinking about gender is associated with preferences for typically maleand female-related professions (Meyer, Cimpian, \& Leslie, 2015). Essentialist thinking lends itself easily to religious cognition, and is inherent in religious concepts of purity and the sacred (Durkheim, 1912; Rozin et al., 1999) that are crucial to religious devotion and rituals (Douglas, 1970). Concepts of divinity are often linked with ideas of purity (Preston \& Ritter, 2012), and ideas contrary to religious convictions elicit symbolic disgust (Ritter et al., 2016). But where essentialist reasoning may be synergistic with religious thinking, it can hinder understanding of scientific processes (Evans, 2001) such as genetics (Heine et al., 2017). In a 2004 U.S. survey, for example, over $50 \%$ of respondents thought that inserting catfish DNA into a tomato would lead the tomato to taste like fish (Hallman et al., 2004). Such essentialist thinking can also lead to misunderstandings of evolution, by treating species as more discrete and homogeneous categories than they in reality are (Evans, 2001; Shtulman \& Schulz, 2008).

Another way that intuitive thinking fits with religious cognition is through teleological thinking - the perception that outcomes are designed toward that end (Kelemen, 1999; 2004). This includes the assumption that there is purpose in how natural phenomena and species operate (e.g., "It rains so that plants and animals have water to drink and grow"; Lombrozo, Kelemen, \& 
Zaitchik, 2007). The teleological stance is related to the intentional stance that perceives mind behind action, but is slanted in particular toward seeing design and purpose to match outcomes. It is easy to see how teleology lends itself to religious ideas. If nature is designed, it must have a designer (i.e., God) that is responsible for devising and crafting these specific forms. Indeed, religious people do rely more on teleological beliefs when reasoning about the causes for events that had an impact on themselves and others (Banerjee \& Bloom, 2014). But like essentialism, teleological thinking can lead to some important misunderstandings of science. Intelligent design (Dembski, 2004) explicitly makes use of intuitive teleological thinking, but cloaks it in scientific language by arguing that specialized outcomes are too unlikely to have emerged by chance, thus appealing to both a teleological and physical stance. However, this teleological reasoning runs counter to evolution by natural selection - an undirected process that creates positive outcomes by random mutations. Yet even professional scientists are susceptible to the appeal of teleological thinking. Kelemen, Rottman, \& Seston (2013) found that scientists were prone to errors they reasoned about the natural world in teleological ways, but only when under time pressure (preventing the more time-consuming analytic reasoning), suggesting an intuitive teleological bias contrary to their explicit (and potentially analytic) beliefs about the machinations of nature.

Religion and science rely on different ways of thinking, especially in the use of faith and intuition over observation and analysis. In some ways, religious cognition has a cognitive advantage over science, because it can make use of intuitive biases that science cannot (McCauley, 2011). But the religious beliefs shaped by these intuitive biases can still be analyzed and tested -perhaps even rejected—by scientific thinking. The nature of the relationship between science and religion therefore largely depends on how they deal with this tension. Are the 
intuitions of religious thinking also able to withstand the scrutiny of scientific analysis? Do the theories of science satisfy our other intuitive biases about the world? If so, science and religion may find a compatibility, or at least be able to dialogue with each other in a meaningful way, as outlined by Barbour (1997). But when intuitions and analysis become irreconcilable, the conflict between science and religion emerges becomes intractable.

\section{Science and religion in action: Morality and mortality concerns.}

As discussed above, key motivations toward explanation, control, and meaning can be addressed by both religion and science. But science and religion are shaped by different processes that affect how these functions are fulfilled. In the final section of this chapter, we reflect on the relationship between religion and science through two major issues: morality (concern for right and wrong) and mortality (concern for life after death). Both morality and mortality concerns are central to religious belief systems, as religion provides specific descriptions of what morality is, and what happens after death. Science does address these questions as well, but with less certainty than religious belief, and often with very different answers. Questions of morality and mortality also reflect concerns related to control, explanation, and meaning. Firstly, morality and mortality are both fundamentally concerned with a fear of chaos and terror, and so can elicit the need to establish control over that chaos. Morality and mortality also entail questions about causality- what is the source of moral goodness; what happens when we die? And of course, both morality and mortality are deeply intertwined with existential meaning, and indeed feelings of meaning or meaninglessness can hinge on our answers to these questions.

Morality. Moral beliefs provide a guide about how to behave and expect others to behave in a society, and moral concerns are at the core of many religious constructs (Preston, 
Salomon, \& Ritter, 2014), theorized to be one of the primary functions of religion, and essential in its social and cultural evolution (Norenzayan \& Shariff, 2008; see other chapters in this volume). Moral beliefs also provide important sources of explanation, control, and meaning. In religious systems, morality is literally handed down from the gods, and religion provides a blueprint for a person to lead a good and righteous life. As moral authorities, gods can enact supernatural rewards and punishment, the consequences for our good and bad actions (Johnson $\&$ Bering, 2006). This alleviates some of the problems of monitoring moral behaviors in a larger society, because gods provide for second order monitoring and punishment (Johnson \& Kruger, 2004). The chaos of an unpoliced society is tempered by ideas of supernatural policing and control. Even if undetected by our fellow mortals on the earthly plane, our actions will be seen and dealt with by higher beings in the hereafter. Morality concepts are integral to religious belief systems, so much so that morality is sometimes treated as synonymous with religion and the divine. A moral life is often considered a holy life, and immorality is considered sinful and demonic. And vice versa; compared to believers, non-believers are seen as immoral, untrustworthy, lacking a moral compass (Gervais, 2013b; Simpson \& Rios, 2017). Interestingly, even atheists hold these attitudes towards fellow atheists, showing it is linked to non-belief itself, and not outgroup prejudice more generally (Gervais, 2014).

Though moral concerns have always been a central issue in religion, morality was not the primary question tackled by science, which is more closely tied with physical systems. Indeed, whether science ought to be involved in morality at all is a philosophical and epistemological question that science has wrestled with (e.g., Harris, 2010; Shermer, 2015; also see Baumard \& Boyer, 2013; De Waal, 2013). Objectivity is a key value of science, and the systematic examination of evidence is intended as a dispassionate investigation of natural laws and 
principles (Merton, 1973). But the traditional mandate for science to be value-neutral may not reflect the prime directive of science: to explain. Some argue it is not possible to achieve an impartial morality any more than a value-neutral science (Houts \& Krasner, 1983). If an important aim of science is to explain, then that includes an understanding of morality and moral judgment. Science aims to be objective in its pursuit of truth, and by doing so can try to discover valid and true bases of morality (Haan, 1982). Science can also be goal-oriented in addressing practical questions, for example, how to lead a good life, and promoting moral actions such as nudging people to give to charity (Bénabou \& Tirole, 2006).

Therefore, science may also become interested in morality, just as religion is (Harris, 2010; McKay \& Whitehouse, 2015). However, the conclusions drawn from scientific views on morality can directly conflict with religion views. This not necessarily in the specific dictums of behavior (e.g., treat others as you would have them treat you), but in the reasons for morality. The very study of the causes of morality from any scientific model may threaten religious authority on morality. In religious belief, gods are not merely the final judge of morality, but the source of morality — morality is handed down from the gods, which speaks to the need for control. In science, morality comes from more mundane sources unconnected to the supernatural, such as intuitions pertaining to fairness and feelings of empathy in predicting moral treatment of others (De Waal, 2013; Norenzayan, 2014). No god is required for morality—an atheist, a heathen, or even nonhumans might behave morally under the direction of empathy and a handful of other moral intuitions.

Scientific models of morality are also more willing to accommodate ideas of relativism in morality — that morality can be learned and flexible, and is shaped by culture (Graham, Haidt \& Nosek, 2009; McKay \& Whitehouse, 2015). In contrast, religion is associated with moral 
absolutes (Yilmaz \& Bahcekapili, 2015), So, where science can accommodate dynamic views of moral change and progress, these can be difficult to reconcile with the notion of an absolute supernatural authority.

Ideas of morality diverge sharply between religion and science, but we can see how they are shaped by common goals for explanation, control, and meaning. Moral systems offer an important sense of control and order in the world - being able to predict and control actions of others good and bad may be the most important concern people face. The need for causal explanation shapes how morality is viewed, as absolute or relative, as originating from divine authority or from psychological processes. Of course, moral beliefs also speak to deeper existential concerns, providing a moral lattice to ascribe meaning. For all these reasons, morality can be a heated issue with potential to arouse conflict between science and religion as separate domains of knowledge. Moreover, there is an additional moral value we ascribe to these systems as cherished worldviews that can motivate us to defend them passionately, rather than allow for dialogue or respectful disagreement: It is hard for people to be objective about moral beliefs, and seemingly impossible for them to be neutral. But where there is room for compatibility between science and religion on morality may be the recognition that there are some fundamental moral intuitions that are universally revered, such as respect for life and freedom from harm.

Mortality. A major component of all religions is the belief in an afterlife - that we each have a soul (or similar concept) that lives on beyond the lifespan of our physical bodies. Belief in the soul may be guided by an intuitive dualism (Bloom, 2006), that we intuitively understand minds as separate from bodies. Minds are in a sense, magical (Wegner, 2008) — they seem to operate outside physical forces - and so we understand them in terms of metaphysical properties (as a soul), rather than natural properties. Intuitive dualism combined with a naïve realism may 
combine to give us a nä̈ve immortality - that is, we do not truly understand that we will die. It is difficult to comprehend the nothingness of death — that mind just goes black upon death — after all, the mind is all we have ever experienced (Preston, Gray \& Wegner, 2006). If the mind does not go black, then what does it do and where does it go? This creates an explanatory need to understand what happens to our minds when our bodies die (Bering, 2006). One way to do this is through religious belief, in particular the concept of a soul. But, if the mind is explained in other ways (i.e., through physical mechanisms of the brain), this seems to reduce the need to believe in a soul (Preston, Ritter, \& Hepler, 2013), despite its possibilities for eternal life. Is the belief in afterlife merely an explanatory issue then? No, not completely. The simplest explanation is that we just die, our bodies rot and our personal consciousness disappears. To most human beings, however, the absolute nothingness of death is both terrifying and unacceptable, and so they seek other more comforting explanations. They are motivated to believe that mortality is not final, that (as Bob Dylan professed) death is not the end.

The motivation to obtain immortality_-literal or symbolic — is at the core of terror management theory (Greenberg, Pyszczynski, \& Solomon, 1986; Greenberg, Solomon, \& Pyszczynski, 1997), which is discussed in depth in other chapters in this volume. Terror management theory was originally conceptualized to explain self-esteem striving and other cultural activity as a form of reactance against the ultimate terror of one's own mortality. Death and mortality arouse deep psychological discomfort and so people are motivated to deny this death through either literal or symbolic immortality. The question of immortality has been primarily the territory of religious and spiritual belief systems (Vail et al., 2010; see also Wojtkowiak \& Rutjens, 2010). Religious beliefs assuage the terror of mortality by offering a comforting alternative: Although one's body may die, one's consciousness and soul can enjoy 
immortality in an afterlife. But religion also provides important symbolic immortality as well: though one may die as an individual, one's cherished belief systems can live on through one's descendants and culture. Thus, mortality is strongly linked to meaning — it is the understanding (and fear) of the finality of death that prompts people to establish a legacy, contribute to culture, and find value in their own brief life while they are still alive.

Some empirical research has looked at the motivation to obtain immortality through science, utilizing terror management theory as a framework. For example, Farias et al. (2013) found that a manipulation of mortality salience increased faith in science. In their study, participants who were instructed to contemplate their mortality subsequently scored higher on a questionnaire that was designed to measure faith in science and the superiority of the scientific method. Other evidence comes from work on the psychological functions of belief in progress (Rutjens et al., 2009). Here, it was found that a mortality reminder led participants to more strongly believe in progress, and that belief in progress provided a psychological buffer against mortality concerns. This research shows that belief in progress can provide people with a sense of symbolic immortality. However, follow-up research qualified this finding by disentangling beliefs in moral-social progress and beliefs in scientific-technological progress (Rutjens et al., 2016). Here, it was found that belief in moral-social but not scientific-technological progress functions as an existential buffer against mortality concerns, and only among participants low in religious belief. Thus, solely believing in scientific and technological advance seems to be insufficient to provide in the need for immortality, either literal or symbolic.

We can see the importance of symbolic immortality through the protection of cherished worldviews - and both religion and science serve as worldviews. These findings converge with research by Tracy, Hart, and Martens (2011). These researchers looked at preference for 
Darwin's theory of evolution versus an intelligent design perspective (also see Rutjens et al., 2010), and found evidence for an increased acceptance of intelligent design — along with a decreased acceptance of evolutionary theory—as a result of a mortality salience manipulation. Intelligent design may provide existential comfort because it is more predictable than evolution by natural selection, and also because it is consistent with religious beliefs about the origins of life. But, natural science students who have already committed to science as their worldview showed the opposite pattern of results. Thus, some initial support for the notion that science can function as an alternative to religion as a meaning-provider was obtained. More specifically, for natural science students, a scientific view on life can be a source of meaning and it seems likely that science was a relatively important value central to those students' identities.

However, other recent work has looked specifically at recent technologies aimed at concretely providing literal immortality, i.e., so-called "indefinite life extension" (ILE) technologies (Lifshin et al., 2018; Vail, Soenke, Waggoner, \& Mavrapoulou, 2019; also see DeGrey \& Rae, 2007). This work showed that mortality concerns increased support for such technologies and quelled mortality concerns, but again only among participants low in religiosity. This research further provide evidence that promises of ILE can replace some psychological functions of beliefs in an afterlife. It is possible that the aforementioned work by Rutjens et al. (2016), which found that belief in scientific-technological progress does not provide a solution to mortality concerns, might have tapped into a general belief that does not speak to (literal) immortality directly enough. In contrast, the ILE research findings indicate that advances in science and technology might indeed help combat existential concerns and provide in the need for immortality, but likely only when these advances provide direct solutions to the problem of mortality (i.e., through concrete technologies that promise literal immortality). In 
sum, recent research on the existential functions of ILE provides evidence that science, like religion, may provide ways to muster hope for literal immortality through new technologies such as genetic engineering, cybernetics, or even cryonics. Regardless of whether people really want immortality (what would they do with eternal life? And would immortality ultimately be existentially gratifying? See, e.g., Gray, 2011), the quest for immortality is as long as the history of death itself. New technologies and advances in science may from now on compete with religion as a means to defeat death and obtain literal rather than mere symbolic immortality.

The matter of our own death is a deep existential issue that speaks to motivations for control, explanation, and finding meaning in our lives. The mystery of death presents an essential epistemological quandary: why do we die, and more importantly, what happens when we die? The inevitability of death puts us face to face with an absolute loss of control and freedom- the control over our own existence- that we can re-establish through some kind of immortality, or an external sense of order in the universe. And the finality of death prompts us to seek meaning in life, to find a purpose and value for the brief time we are here. Religious beliefs address all these issues through ideas of the soul and the afterlife, and a set of prescribed moral behaviors to achieve that immortality. As a natural, physical issue, problems of death can be addressed by science as well. In the aptly titled "The Immortalization Commission: Science and the Strange Quest to Cheat Death", it is argued that scientific quest to conquer death was already set in motion in Victorian times (Gray, 2011). Given the close relation between existential needs and immortality motivations, recent developments in science and technology might help to combat existential concerns by promising a direct solution to the problem of mortality.

\section{Conclusion}


We started this chapter with a brief introduction to the history and complexities of the relation between science and religion. Oftentimes, there seems to be an incompatibility between the scientific and the religious worldviews (Preston \& Epley, 2009), especially when viewed as opposing forces. This brings us to another important question: Is there room for religion in science, and vice versa? In a culture that promotes conflict between science and religion, who wins? In some ways, religion has a competitive edge (also see Laurin \& Kay, 2017) over scientific beliefs as it employs intuitive thinking styles and directly addresses concerns with absolutism and certainty. But even when science is uncertain, it offers objectivity and a means of approaching truth through systematic analysis (Firestein, 2016). So neither system is likely to win, but will likely continue to be employed in different ways that will surely fluctuate with time: The mysteries of today are the scientific breakthroughs of tomorrow.

Like others, we argue that religion and science do not necessarily conflict, but can be treated as separate, compatible, or used to inform each other in non-overlapping but complementary ways. As we have described, science and religion differ in underlying assumptions and processes that shape religious and scientific ideas, and in how they inform important topics like morality and mortality. At the same time, science and religion share key psychological functions for explanation, control, and meaning. The relationship between the two depends on how these belief systems fulfill their key psychological functions for explanation, control, and meaning. When they conflict, science and religion have contradictory explanations, sources of control, or existential conclusions. When they are compatible, these functions work with each other. Either way, these core psychological functions remain central to both science and religion, and ultimately provide an important contribution in shaping the nature of their relationship. 


\section{References}

Abeyta, A. A., \& Routledge, C. (2018). The need for meaning and religiosity: An individual differences approach to assessing existential needs and the relation with religious commitment, beliefs, and experiences. Personality and Individual Differences, 123, 6-13.

Atran, S., \& Norenzayan, A. (2004). Religion's evolutionary landscape: Counterintuition, commitment, compassion, communion. Behavioral and Brain Sciences, 27, 713-730.

Baumard N, \& Boyer P (2013) Explaining moral religions. Trends in Cognitive Sciences, 17, $172-180$.

Barbour, I. G. (1997). Religion and Science: Historical and Contemporary Issues. San Franscisco, CA: Harper Collins

Bénabou, R., \& Tirole, J. (2006). Incentives and prosocial behavior. American Economic Review, 96, 1652-1678.

Bender, J., Rothmund, T., Nauroth, P., \& Gollwitzer, M. (2016). How moral threat shapes laypersons' engagement with science. Personality and Social Psychology Bulletin, 42, 17231735 .

Blancke, S., De Smedt, J., De Cruz, H., Boudry, M., \& Braeckman, J. (2012). The implications of the cognitive sciences for the relation between religion and science education: the case of evolutionary theory. Science \& Education, 21, 1167-1184.

Cimpian, A., \& Salomon, E. (2014). The inherence heuristic: An intuitive means of making sense of the world, and a potential precursor to psychological essentialism. Behavioral and Brain Sciences, 37, 461-480. 
Rutjens \& Preston - Science and religion

Cowgill, C. M., Rios, K., \& Simpson, A. (2017). Generous heathens? Reputational concerns and atheists' behavior toward Christians in economic games. Journal of Experimental Social Psychology, 73, 169-179.

Crumbaugh, J. C., \& Maholick, L. T. (1964). An experimental study in existentialism: The psychometric approach to Frankl's concept of noogenic neurosis. Journal of clinical psychology, 20, 200-207.

De Grey, A., \& Rae, M. (2007). Ending aging: The rejuvenation breakthroughs that could reverse human aging in our lifetime. Macmillan.

De Waal, F. (2013) The bonobo and the atheist: In search of humanism among the primates. New York: W.W. Norton.

Dembski, W. A. (2004). The Design Revolution. England: Intervarsity Press

Dennett, D. C. (1987). The Intentional Stance. Cambridge, MA: MIT Press.

Evans, E. M. (2001). Cognitive and contextual factors in the emergence of diverse belief systems: Creation versus evolution. Cognitive Psychology, 42, 217-266.

Farias, M., Newheiser, A. K., Kahane, G., \& de Toledo, Z. (2013). Scientific faith: Belief in science increases in the face of stress and existential anxiety. Journal of Experimental Social Psychology, 49, 1210-1213.

Firestein, S. (2016). Failure. Why science is so successful. Oxford University Press, UK.

Haan, N. (1982). Can research on morality be "scientific"?. American psychologist, 37, 1096.

Houts, A. C., \& Krasner, L. (1983). Values in science: Comment on Haan. American Psychologist, 38, 1253-1254.

Galen, L. W. (2012). Does religious belief promote prosociality? A critical examination. Psychological Bulletin, 138, 876. 
Rutjens \& Preston - Science and religion

Gervais, W. M. (2013b). In godlessness we distrust: Using social psychology to solve the puzzle of anti-atheist prejudice. Social and Personality Psychology Compass, 7, 366-377.

Gervais, W. M. (2013a). Perceiving minds and gods: How mind perception enables, constrains, and is triggered by belief in gods. Perspectives on Psychological Science, 8, 380-394.

Gervais, W. M. (2014). Everything is permitted? People intuitively judge immorality as representative of atheists. PloS one, 9, e92302.

Gould, S. J. (1997). Nonoverlapping magisteria. Natural history, 106, 16-22.

Graham, J., Haidt, J., Nosek, B. A. (2009). Liberals and conservatives rely on different sets of moral foundations. Journal of Personality and Social Psychology, 96, 1029-1046.

Gray, J. (2011). The immortalization commission: Science and the strange quest to cheat death. Macmillan.

Harris S (2010) The moral landscape: How science can determine human values. New York: Free Press.

Haselton, M. G., \& Nettle, D. (2006). The paranoid optimist: an integrative evolutionary model of cognitive biases. Personality and Social Psychology Review, 10(1), 47-66.

Hassin, R., Bargh, J. A., \& Uleman, J. S. (2002). Spontaneous causal inferences. Journal of Experimental Social Psychology, 38, 515-522.

Hawking, S. (2006). The theory of everything. Jaico Publishing House.

Heckhausen, J., \& Schulz, R. (1995). A life-span theory of control. Psychological Review, 102, 284-304.

Heine, S. J., Dar-Nimrod, I., Cheung, B. Y., \& Proulx, T. (2017). Essentially biased: Why people are fatalistic about genes. In J. Olson (Ed.), Advances in Experimental Social Psychology, Vol. 55. (pp. 137-192). Cambridge, MA: Academic Press. 
Johnson, D., \& Bering, J. (2006). Hand of God, mind of man: Punishment and cognition in the evolution of cooperation. Evolutionary Psychology, 4, 147470490600400119.

Johnson, K. A., Moon, J. W., Okun, M. A., Scott, M. J., O'Rourke, H. P., Hook, J. N., \& Cohen, A. B. (2019). Science, God, and the cosmos: Science both erodes (via logic) and promotes (via awe) belief in God. Journal of Experimental Social Psychology, 84, 103826.

Keil, F. C. (2006). Explanation and Understanding. Annual Review of Psychology, 57, 227-254.

Kelemen, D. (2004). Are children "intuitive theists"? Reasoning about purpose and design in nature. Psychological Science, 15, 295-301.

Kelemen, D., (1999). Why are rocks pointy? Children's preference for teleological explanations of the natural world. Developmental Psychology, 35, 1440-1452.

Keleman, D., Rottman, J., \& Seston, R. (2013). Professional physical scientists display tenacious teleological tendencies: Purpose-based reasoning as a cognitive default. Journal of Experimental Psychology: General, 142, 1074-1083.

Khenfer, J., Roux, E., Tafani, E., \& Laurin, K. (2017). When God's (not) needed: Spotlight on how belief in divine control influences goal commitment. Journal of Experimental Social Psychology, 70, 117-123.

Landau, M. J., Kay, A. C., \& Whitson, J. A. (2015). Compensatory control and the appeal of a structured world. Psychological Bulletin, 141, 694.

Landau, M. J., Khenfer, J., Keefer, L. A., Swanson, T. J., \& Kay, A. C. (2018). When and why does belief in a controlling God strengthen goal commitment?. Journal of Experimental Social Psychology, 75, 71-82.

Laughlin, R. B., \& Pines, D. (2000). The theory of everything. Proceedings of the National Academy of Sciences, 97, 28-31. 
Rutjens \& Preston - Science and religion

Laurin, K., \& Kay, A. C. (2017). The motivational underpinnings of belief in God. In Advances in experimental social psychology (Vol. 56, pp. 201-257). Academic Press.

Legare, C. H., Evans, E. M., Rosengren, K. S., \& Harris, P. L. (2012). The coexistence of natural and supernatural explanations across cultures and development. Child Development, 83(3), 779-793.

Lifshin, U., Greenberg, J., Soenke, M., Darrell, A., \& Pyszczynski, T. (2017). Mortality salience, religiosity, and indefinite life extension: Evidence of a reciprocal relationship between afterlife beliefs and support for forestalling death. Religion, Brain \& Behavior, 113.

Lombrozo, T., Kelemen, D., Zaitchik, D. (2007). Inferring design: evidence of a preference for teleological explanations in patients with Alzheimer's Disease. Psychological Science, 18, 999-1006.

McCauley, R. N. (2011). Why religion is natural and science is not. Oxford University Press.

McKay, R., Efferson, C., Whitehouse, H., \& Fehr, E. (2011). Wrath of God: Religious primes and punishment. Proceedings of the Royal Society of London B: Biological Sciences, 278, 1858-1863. doi:10.1098/rspb.2010.2125

McKay R., \& Whitehouse, H. (2015) Religion and Morality. Psychological Bulletin, 141, 447.

Merton, R. K. (1973). The sociology of science: Theoretical and empirical investigations. Chicago: Chicago University Press.

Meyer, M., Cimpian, A., \& Leslie, S. J. (2015). Women are underrepresented in fields where success is believed to require brilliance. Frontiers in Psychology, 235.

Morewedge, C. K. (2009). Negativity bias in attribution of external agency. Journal of Experimental Psychology: General, 138, 535. 
Rutjens \& Preston - Science and religion

Newton, T., \& McIntosh, D. N. (2013). Unique contributions of religion to meaning. In The experience of meaning in life (pp. 257-269). Springer, Dordrecht.

Norenzayan A (2014) Does religion make people moral? Behaviour, 151, 365-384.

Norenzayan, A., Atran, S., Faulkner, J., \& Schaller, M. (2006). Memory and mystery: The cultural selection of minimally counterintuitive narratives. Cognitive Science, 30, 531-553

Norenzayan, A., \& Shariff, A. F. (2008). The origin and evolution of religious prosociality. Science, 322, 58-62. doi:10.1126/science .1158757

Preston, J. L. \& Coleman, T. (2011). Religion is the opiate of the masses (but science is the methadone). Religion, Brain, \& Behavior, 1, 231-233.

Preston, J. L. (2019). Spirituality of Science: Evidence for a construct. Unpublished Manuscript in Preparation. University of Warwick, UK.

Preston, J. \& Epley, N. (2005). Explanations versus applications: The explanatory power of valuable beliefs. Psychological Science, 16, 826-832.

Preston, J. \& Epley, N. (2009). Science and God: An automatic opposition between ultimate explanations. Journal of Experimental Social Psychology, 45, 238-241.

Preston, J., Gray, K., \& Wegner, D. M. (2006). The Godfather of soul. Behavioral and Brain Sciences, 29, 482-483.

Preston, J. L. \& Ritter, R. S. (2012). Cleanliness and godliness: Mutual association between two forms of personal purity. Journal of Experimental Social Psychology, 48, 1365-1368.

Preston, J. L., Ritter, R. S., \& Hepler, J. (2013). Neuroscience and the soul: Competing explanations for the human experience. Cognition, 127, 31-37. 
Rutjens \& Preston - Science and religion

Preston, J. L., Salomon, E., \& Ritter, R. S. (2014). Religious prosociality: Personal, cognitive, and social factors. In V. Saroglou (Ed.), Religion, Personality, and Social Behavior (pp.149-169). New York, NY: Psychology Press.

Preston, J. L. \& Shin, F. (2017). Spirituality induces awe through the small self in religious and non-religious individuals. Journal of Experimental Social Psychology, 70, 212-221.

Shenhav, A., Rand, D. G., \& Greene, J. D. (2012). Divine intuition: Cognitive style influences belief in God. Journal of Experimental Psychology: General, 141, 423.

Ritter, R. S., Preston, J. L., Salomon, E. S., \& Johnson, D. R. (2016). Imagine no religion: Heretical disgust, anger, and the symbolic purity of mind. Cognition and Emotion, 30, 778796.

Ritter, R. S., Preston, J. L., \& Hernandez, J.I. (2014). Happy tweets: Christians are happier, more socially connected, and less analytical than atheists on Twitter. Social Psychological and Personality Science, 5, 243-249.

Rothbaum, F., Weisz, J. R., \& Snyder, S. S. (1982). Changing the world and changing the self: A two-process model of perceived control. Journal of Personality and Social Psychology, 42, $5-37$.

Rozin, P., Lowery, L., Imada, S., \& Haidt, J. (1999). The CAD triad hypothesis: a mapping between three moral emotions (contempt, anger, disgust) and three moral codes (community, autonomy, divinity). Journal of Personality and Social Psychology, 76, 574.

Rutjens, B. T., Heine, S. J., Sutton, R. M., \& van Harreveld, F. (2018). Attitudes towards science. Advances in Experimental Social Psychology, 57, 125-165.

Rutjens, B. T., \& Kay, A. C. (2017). Compensatory Control Theory and the psychological importance of perceiving order. In M. Bukowski, I. Fritsche, A. Guinote, \& M. Kofta 
Rutjens \& Preston - Science and religion

(Eds.), Current Issues in Social Psychology - Coping with lack of control in a social world (pp. 83-97). New York: Routledge.

Rutjens, B. T., Sutton, R. M., \& van der Lee, R. (2018). Not all skepticism is equal: Exploring the ideological antecedents of science acceptance and rejection. Personality and Social Psychology Bulletin, 44, 384-405.

Rutjens, B. T., \& van Elk, M. (2019). Can science provide meaning? Belief system predictors of meaning in life tested across different populations. Manuscript in preparation.

Rutjens, B. T., van Harreveld, F., \& van der Pligt, J. (2013). Step by step: Finding compensatory order in science. Current Directions in Psychological Science, 22, 250-255.

Rutjens, B. T., van Harreveld, F., van der Pligt, J., van Elk, M., \& Pyszczynski, T. (2016). A march to a better world? Religiosity and the existential function of belief in social-moral progress. International Journal for the Psychology of Religion, 26(1), 1-18.

Rutjens, B. T., van der Pligt, J., \& van Harreveld, F. (2010). Deus or Darwin: Randomness and belief in theories about the origin of life. Journal of Experimental Social Psychology, 46, 1078-1080.

Rutjens, B. T., van Harreveld, F., van der Pligt, J., Kreemers, L. M., \& Noordewier, M. K. (2013). Steps, stages, and structure: Finding compensatory order in scientific theories. Journal of Experimental Psychology: General, 142, 313-318.

Sedikides, C. (2010). Why does religiosity persist?. Personality and Social Psychology Review, $14,3-6$.

Shermer, M. (2015). The moral arc. New York, NY: Henry Holt.

Shtulman, A., \& Schulz, L. (2008). The relation between essentialist beliefs and evolutionary reasoning. Cognitive Science, 32, 1049-106. 
Rutjens \& Preston - Science and religion

Simpson, A., \& Rios, K. (2017). The moral contents of anti-atheist prejudice (and why atheists should care about it). European Journal of Social Psychology, 47, 501-508.

Steger, M. F., Frazier, P., Oishi, S., \& Kaler, M. (2006). The meaning in life questionnaire: Assessing the presence of and search for meaning in life. Journal of counseling psychology, 53, 80 .

Steger, M. F., \& Frazier, P. (2005). Meaning in life: One link in the chain from religiousness to well-being. Journal of Counseling Psychology, 52, 574.

Thagard, P. (1989). Explanatory coherence. Behavioral and Brain Sciences, 12, 435-467.

Thagard, P., \& Findlay, S. (2010). Getting to Darwin: Obstacles to accepting evolution by natural selection. Science \& Education, 19(6-8), 625-636.

Thompson, S. C., \& Spacapan, S. (1991). Perceptions of control in vulnerable populations. Journal of Social Issues, 47, 1-21.

Tracy, J. L., Hart, J., \& Martens, J. P. (2011). Death and science: The existential underpinnings of belief in intelligent design and discomfort with evolution. PloS one, 6, e17349.

Vail, K. E., Rothschild, Z. K., Weise, D. R., Solomon, S., Pyszczynski, T., \& Greenberg, J. (2010). A terror management analysis of the psychological functions of religion. Personality and Social Psychology Review, 14, 84-94.

Vail III, K. E., Soenke, M., Waggoner, B., \& Mavropoulou, I. (2019). Natural, But Not Supernatural, Literal Immortality Affirmation Attenuates Mortality Salience Effects on Worldview Defense in Atheists. Personality and Social Psychology Bulletin, 0146167219855051.

Valdesolo, P., \& Graham, J. (2014). Awe, uncertainty, and agency detection. Psychological science, $25,170-178$. 
Rutjens \& Preston - Science and religion

Valdesolo, P., Park, J., \& Gottlieb, S. (2016, Oct). Awe and scientific explanation. Emotion, 16, 937-940. http://dx.doi.org/10.1037/emo0000213.

Valdesolo, P., Shtulman, A., \& Baron, A. S. (2017). Science is awe-some: The emotional antecedents of science learning. Emotion Review, 9, 215-221.

Van Cappellen, P., \& Saroglou, V. (2012). Awe activates religious and spiritual feelings and behavioral intentions. Psychology of Religion and Spirituality, 4, 223-236.

Van Elk, M., Rutjens, B. T., van der Pligt, J., \& Van Harreveld, F. (2016). Priming of supernatural agent concepts and agency detection. Religion, Brain \& Behavior, 6(1), 4-33.

Wegner, D.M. (2008). Self is magic. In: J Baer, JC Kaufman, \&RF Baumeister (Eds.) Are we free? Psychology and free will. (pp. 226-247). New York: Oxford University Press.

Weiner, B. (1985). Spontaneous causal thinking. Psychological Bulletin, 97, 74-84.

Wilson, T. D., Centerbar, D. B., Kermer, D. A., \& Gilbert, D. T. (2005). The pleasures of uncertainty: prolonging positive moods in ways people do not anticipate. Journal of personality and social psychology, $88,5$.

Wojtkowiak, J., \& Rutjens, B. T. (2011). The postself and terror management theory: Reflecting on after death identity buffers existential threat. International Journal for the Psychology of Religion, 21, 137-144.

Wojtkowiak, J.,Rutjens, B. T., \& Venbrux, E. (2010). Meaning making and death: A Dutch survey study. Archive for the Psychology of Religion, 32, 363-373.

Woolley, J. D., Cornelius, C. A., \& Lacy, W. (2011). Developmental changes in the use of supernatural explanations for unusual events. Journal of Cognition and Culture, 11(3-4), 311-337. 
Rutjens \& Preston - Science and religion

Yilmaz, O., \& Bahcekapili, H. G. (2015). Without God, everything is permitted? The reciprocal influence of religious and meta-ethical beliefs. Journal of Experimental Social Psychology, 58, 95-100. 